\title{
Organic geochemistry of Cretaceous black shales from the Galicia Margin, Ocean Drilling Program Leg 103
}

\author{
Philip A. Meyers*, Keith W. Dunham and Elleen S. Ho \\ Marine Geology Program, Department of Geological Sciences, The University of Michigan, Ann Arbor, \\ MI 48109-1063, U.S.A
}

\begin{abstract}
Organic-carbon-rich "black shales" from three different Cretaceous episodes sampled during Ocean Drilling Program Leg 103 have been studied by organic geochemical methods. Rock-Eval analysis, carbon isotope data, and lipid biomarkers show organic matter to contain varying proportions of marine and continental materials. In Hauterivian-Barremian organic-carbon-rich turbiditic marlstones, major amounts of land-derived organic matter are found. Aptian-Albian black-colored shales are interspersed within green claystones, from which they differ by containing more marine organic matter. An abbreviated layer of black shale from the Cenomanian-Turonian boundary is dominated by well-preserved marine organic matter. Downslope transport and rapid reburial within a predominantly oxygenated deepwater setting created most of these examples of black shales, except for the Cenomanian-Turonian deposits in which deepwater anoxia may have been involved.
\end{abstract}

Key words: black shales, Galicia Margin, $n$-alkanes, $n$-alkanoic acids, $n$-alkanols, Rock-Eval, $\delta^{13} \mathrm{C}$, Cretaceous sediments, ODP Leg 103

\section{INTRODUCTION}

The presence of organic-carbon-rich layers of Cretaceous rocks has been documented at many of the locations in the North Atlantic Ocean which have been studied by the Deep Sea Drilling Project. Although their lithologies often vary, these "black shales" share the traits of being darker in color and richer in organic matter than typical deep-ocean sediments and sedimentary rocks. Because the amounts and types of organic matter buried in sediments is influenced both by the oceanographic and depositional conditions existing at the time of sedimentation and by subsequent postdepositional processes, study of the organic constituents of black shales can provide information about the many factors involved in their formation.

\section{LITHOLOGIC SETTING}

Drilling during Leg 103 was done at five sites on the Galicia Margin (Fig. 1) to obtain samples of sedimentary rocks which record the history of the eastern North Atlantic from the early stages of subsidence and rifting, through spreading of this ocean, to near-modern conditions. The results from the five sites have been combined to form a composite lithostratigraphic column (Boillot et al., 1985) which illustrates that the lithologic units common to most of the North Atlantic seafloor (Jansa et al., 1978) exist also on the margin of the Iberian Peninsula. A thick limestone, marlstone, and sandstone sequence corresponding to the Blake-Bahama Formation was deposited on the Galicia Margin from Tithonian to

*Author to whom correspondence should be addressed.
Barremiam times (152-119 Mya). This was followed by accumulation of debris flows and turbidites and then by bioturbated claystones in which black shales were interspersed. This unit, corresponding to the Hatteras Formation, extends from Aptian to Cenomanian (119-91 Mya) strata. Drilling during Leg 103 was concentrated on older objectives, and hence full sections of units younger than middle Cretaceous were not recovered.

\section{METHODS}

Samples selected for analysis of their organic matter contents, which are relatively labile to microbial attack and alteration, were frozen upon collection and kept frozen until analyses began. The samples were freeze-dried as the first step in their study. Calcium carbonate contents were determined by the carbonate bomb technique (Müller and Gastner, 1971). Residual carbon was measured with a Hewlett-Packard 185B CHN Analyzer after $\mathrm{HCl}$ dissolution of carbonates and was considered to represent the total organic carbon content. Organic matter atomic $\mathrm{C} / \mathrm{N}$ ratios were determined from residual carbon values. Organic carbon concentrations of the samples were calculated on a dryweight basis for the original, carbonate-containing rock. Determination of the stable carbon isotope ratios of the organic carbon content of these samples was done using a VG Micromass 602 mass spectrometer calibrated with NBS-20 (carbonate) and NBS-21 (graphite) standards. Data are corrected for ${ }^{17} \mathrm{O}$ and are presented relative to the PDB standard (Craig, 1953). Rock-Eval analyses were done onboard the JOIDES Resolution using a Delsi Nermag Rock-Eval II instrument. 


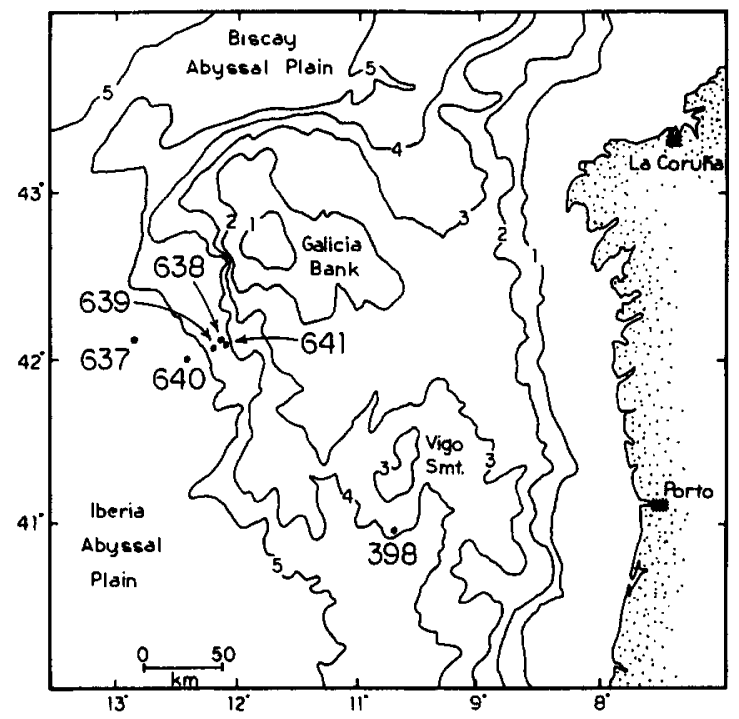

Fig. 1. Locations of Leg 103 sites and of DSDP Site 398. Bathymetric details are from Sibuet et al. (1987). Depth contours are in kilometers.

As part of the analysis scheme, an extraction procedure was used which provided solventextractable lipids. These fractions are called free in this report, but no implications about the presence or absence of chemical bonds are intended. Free lipids were obtained from samples of freeze-dried sediment by Soxhlet extraction with toluene/methanol for $24 \mathrm{~h}$. After being concentrated, lipid extracts were saponified and then methylated with methanolic boron trifluoride as described by Leenheer et al. (1984).

Internal standards of C-36 $n$-alkane and of methyl heptadecanoate were added to each subsample. Column chromatography of each sample on a column packed with aluminum oxide over silica gel as detailed by Leenheer et al. (1984) provided four fractions: hydrocarbons (saturated plus aromatic), fatty acid methyl esters, a sterol-alcohol fraction, and a column wash. The sterol/alcohol fractions were derivatized with BSTFA and an internal standard of $5 \alpha$-cholestane was added for quantification by gas chromatography.

Hydrocarbon, fatty acid methyl ester, and fatty alcohol silyl ether fractions were analyzed using a Hewlett-Packard 5830A FID gas chromatograph equipped with a $20 \mathrm{~m}$ SE-54 capillary column and fitted with a splitless injection system. Hydrogen was used as the carrier gas and nitrogen as the makeup gas. Quantitative results were obtained using the internal standard amounts after corrections were made with response factors calculated from standard mixes. The reported results have been further corrected for small amounts of laboratory contamination as determined from blank analyses.

\section{RESULTS AND DISCUSSION}

\section{Organic carbon and organic matter $C / N$ ratios}

Neocomian (144-119 Mya) claystones and marlstones have organic carbon percentages ranging from 0.16 to 3.0 (Table 1); this sequence is equivalent in lithology and overall organic matter characteristics to the Blake-Bahama Formation of the western North Atlantic Basin. Aptian-Albian (119-97 Mya) claystones are somewhat higher in organic carbon content than the older carbonate sequence, having values as great as $4.90 \%$. An abbreviated sequence of green and black claystones was obtained in Hole 641A at the Cenomanian-Turonian boundary (91 Mya). Organic carbon concentrations reach $10.34 \%$ in one sample from this short sequence. The combination of Aptian to Cenomanian predomi-

Table 1. General characteristics of Cretaceous "black shales" and adjacent rocks from Leg 103 drill holes

\begin{tabular}{|c|c|c|c|c|}
\hline Sample & Lithology & $\% \mathrm{C}_{\text {org }}$ & $\mathbf{C} / \mathrm{N}^{a}$ & $\delta^{13} \mathrm{C}^{6}$ \\
\hline \multicolumn{5}{|c|}{ Blake-Bahama Formation } \\
\hline \multicolumn{5}{|l|}{ Hauterivian samples } \\
\hline $638 \mathrm{~B}-35-4,86-91 \mathrm{~cm}$ & Dark gray claystone & 3.00 & 76 & -25.8 \\
\hline $\begin{array}{l}638 \mathrm{~B}-26-1,14-19 \mathrm{~cm} \\
\text { Barremian } \\
\text {. }\end{array}$ & Dark gray marlstone & 1.46 & 30 & -26.5 \\
\hline $638 \mathrm{~B}-23-3,20-26 \mathrm{~cm}$ & Dark gray turbiditic maristone & 2.39 & 46 & -26.8 \\
\hline $638 \mathrm{~B}-23-2,139-145 \mathrm{~cm}$ & Light gray marlstone & 0.16 & 47 & -26.7 \\
\hline $638 \mathrm{~B}-23-2,19-25 \mathrm{~cm}$ & Dark gray turbiditic marlstone & 2.03 & 49 & -26.7 \\
\hline \multicolumn{5}{|c|}{ Hatteras Formation } \\
\hline \multicolumn{5}{|l|}{ Albian samples } \\
\hline $641 \mathrm{C}-2-5,57-60 \mathrm{~cm}$ & Green claystone & 0.15 & 7 & -25.1 \\
\hline $641 \mathrm{C}-2-4,3-6 \mathrm{~cm}$ & Black shale & 4.38 & 20 & -28.1 \\
\hline $641 \mathrm{C}-1 \cdot 2,68-72 \mathrm{~cm}$ & Black shale & 4.90 & 20 & -27.4 \\
\hline $641 \mathrm{C}-1-2,49-52 \mathrm{~cm}$ & Black shaje & 3.63 & 19 & -27.6 \\
\hline $\begin{array}{l}641 \mathrm{C}-1-1,20-24 \mathrm{~cm} \\
\text { Cenomanian samples }\end{array}$ & Black shate & 1.18 & 9 & -27.1 \\
\hline $641 \mathrm{~A}-6 \mathrm{cc}, 31-34 \mathrm{~cm}$ & Green Claystone & 0.25 & 9 & $-25.2 \pm 0.1$ \\
\hline $641 \mathrm{~A}-60 \mathrm{c}, 3-6 \mathrm{~cm}$ & Black shale & 10.34 & ND & -23.9 \\
\hline $641 \mathrm{~A}-6-7,21-24 \mathrm{~cm}$ & Green claystone & 0.11 & ND & $-24.4 \pm 0.2$ \\
\hline
\end{tabular}

$\mathrm{ND}=$ not determined.

- $\mathrm{C} / \mathrm{N}$ ratios are given as atomic ratios.

${ }^{b}$ Isotope ratios of organic carbon are given in per mille relative to the PDB standard, with mean \pm standard deviation for replicates. 
nantly green and black claystones is equivalent to the Hatteras Formation. Atomic $\mathrm{C} / \mathrm{N}$ ratios of organic matter show several important distinctions among the various lithologic types. Carbonate-rich Neocomian rocks have relatively high $\mathrm{C} / \mathrm{N}$ values, between 30 and 76, regardless of organic carbon contents. In contrast, Albian and Cenomanian claystones have $\mathrm{C} / \mathrm{N}$ ratios related to their organic carbon concentrations. Organic-carbon-rich black shales average 18 in $\mathrm{C} / \mathrm{N}$, whereas organic-carbon-poor green claystones have values averaging 8 (Dunham et al., 1988). These differences parallel those found in equivalent lithologies at Site 603 on the outer Hatteras Rise (Dunham et al., 1987).

\section{Carbon isotope and Rock-Eval analyses}

Carbon isotope ratios of these Cretaceous samples, expressed in the conventional $\delta^{13} \mathrm{C}$ notation in Table 1, range between -23.9 and $-28.1 \%$, which is not a broad variation considering the considerable contrasts in sample ages and lithologic types. The excursion in carbon isotope ratios, in which Cretaceous rocks richer in marine organic matter have lighter $\delta^{13} \mathrm{C}$ values than found in modern marine organic carbon (Dean et al., 1986), is not strongly developed in these eastern North Atlantic samples. In this regard, these ${ }^{13} \mathrm{C}$ data resemble those of rocks from DSDP Sites 398 and 402, also in the eastern part of this ocean (Erdman and Schorno, 1979a, b). Little difference in isotopic content is present between rocks rich or poor in organic matter. Because most of these isotopic values fall midway between the $\delta^{13} \mathrm{C}$ ratios of $-21 \pm 1$ and $-29 \pm 1 \%$ reported by Peterson et al. (1985) for modern marine plankton and modern C-3 land plants, respectively, they are not particularly diagnostic as source indicators, suggesting only a mixture of marine and continental material in this ocean margin setting.

Rock-Eval pyrolysis is intended for rocks having organic matter that is more thermally mature and at somewhat higher concentrations than is commonly found at ODP sites. Nonetheless, Rock-Eval data have been useful in helping to characterize organic matter in DSDP and ODP samples. Comparison of the hydrogen and oxygen indices of HauterivianBerremian, Aptian-Albian, and Cenomanian samples from Leg 103 shows two trends (Fig. 2). First, black shales generally have higher hydrogen indices and lower oxygen indices than do interbedded organiccarbon-lean strata. Second, black shales become progressively more hydrogen-rich from Neocomian to Cenomanian deposits. As described in the Site Summary chapters (Boillot et al., 1987), $T_{\max }$ values are in the range of $400-420^{\circ} \mathrm{C}$, which is typical of immature organic matter (Espitalie et al., 1977).

\section{Extractable alkanes, alkanoic acids and alkanols}

Concentrations of extractable geolipids are listed in Table 2 in terms of micrograms per gram dry sample and per gram organic carbon in that sample. In comparison to samples of similar ages and lithologies from Site 603 in the western North Atlantic (Dunham et al., 1987), the absolute concentrations of $n$-alkanes and $n$-alkanols in these eastern North Atlantic rocks are similar to those found on the Hatteras Rise. Concentrations of $n$-alkanoic acids, however, are generally lower in these eastern margin samples than in the Site 603 rocks, perhaps reflecting more diagenetic reworking of the organic matter in the eastern location, inasmuch as fatty acids are more sensitive to such losses than are the other classes of geolipids. The Cenomanian samples from Hole 641A have notable higher absolute concentrations of $n$ alkanes than other Leg 103 rocks and contain more of these hydrocarbons than do Cenomanian samples from Site 603. As seen in the Rock-Eval data (Fig. 2), the Cenomanian samples at Hole 641C contain the greatest proportion of marine-type organic matter of any of the rocks surveyed in this study, and their geolipid contents evidently reflect this factor.

The concentrations of geolipids expressed relative to the organic carbon contents of the rocks are generally low and are similar to the relative concentrations found in Cretaceous samples from Site 603

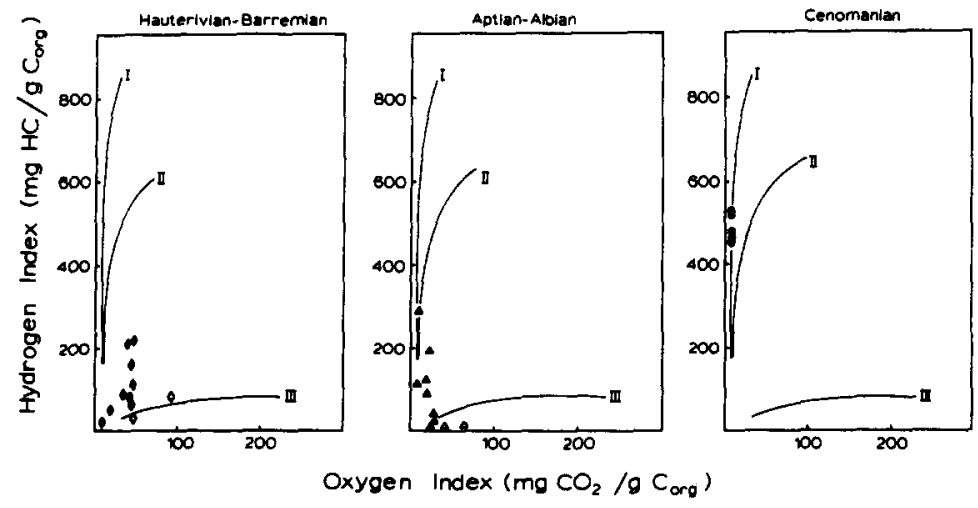

Fig. 2. Comparison of Rock Eval analyses of rocks from the three episodes of black shale deposition on the Galician Margin. Solid symbols represent data from "black shales"; open symbols are from organic-carbon-poor rocks. 


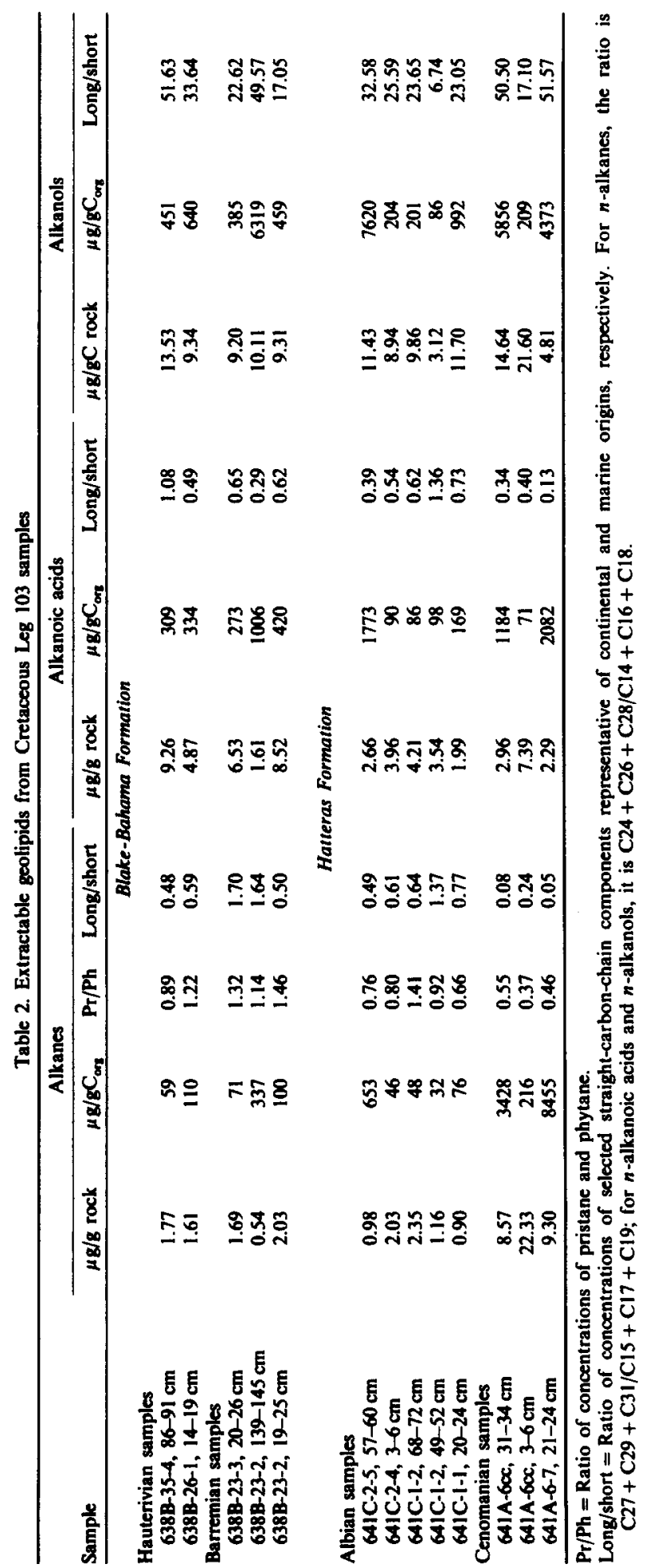


(Dunham et al., 1987). Black shales, in particular, are lean in relative proportions of extractable geolipids. This low amount of available hydrocarbons is consistent with the low thermal maturity of the samples as given by the Rock-Eval data (Site Summeries, Boillot et al., 1987).

Included in Table 2 are ratios of geolipid components which summarize some aspects of the molecular distributions present in these extractable materials. The isoprenoid hydrocarbons pristane and phytane are at concentrations nearly the same as those of the closely eluting $\mathrm{Cl} 7$ and $\mathrm{C} 18 \boldsymbol{n}$-alkanes. Ratios of pristane to phytane vary between 0.37 and 1.46, showing no relationship to sample lithology, organic carbon content, $\delta^{13} \mathrm{C}$ value, or Rock-Eval indices. The lowest pristane/phytane ratios are found in Cenomanian samples, perhaps recording greater amounts of methanogenic bacterial activity during the deposition of these younger sediments (Risatti $e t$ al., 1984; Dunham et al., 1987). Ratios of long-chainlength components of the $n$-alkane, $n$-alkanoic acid, and $n$-alkanol fractions to the short-chain-length components of these sample extracts are given as rough indicators of land-plant wax contributions relative to lipid inputs from aquatic sources (cf. Simoneit, 1978). Most of the long/short ratios of the $n$-alkane and $n$-alkanoic fractions are low, suggesting a predominance of aquatic lipids, but the $n$-alkanol long/short ratios are consistently much larger, giving a contractory, terrigenous source indication for these geolipid components. The conflict in geolipid source signals suggests that more than one origin exists for the extractable matter present in these samples or that diagenesis has altered their original source character.

Comparisons of the distributions of individual $n$-alkanes, $n$-alkanoic acids, and $n$-alkanols imply that several sources have indeed been involved in constituting the geolipid compositions of these Cretaceous rocks. Distributions of $n$-alkanes are generally dominated by components in the $\mathrm{C}_{15}-\mathrm{C}_{21}$ range (Fig. 3). These hydrocarbons do not display the strong odd-over-even chain-length predominance typically found in organisms. In fact, even-carbonnumbered $n$-alkanes are the most abundant compound in six of the ten distributions. Such absence of odd-over-even predominance suggests that these hydrocarbons arise from diagenetically altered material (Simoneit, 1986), and they may represent recycled detrital organic matter eroded from continental sources. The presence of continental material is further implied in the Hauterivian and Barremian examples shown in Fig. 3 by significant proportions of longer chain-length $n$-alkanes having stronger odd-over-even preferences. These hydrocarbons, in the $\mathrm{C}_{27}-\mathrm{C}_{33}$ range, are indicative of the waxy coatings of land plants (Eglinton and Hamilton, 1963; Simoneit, 1978, 1986). In contrast, the Cenomanian $n$-alkane distributions contain very small proportions of these longer chain-length materials. Because the concentrations of hydrocarbons are significantly

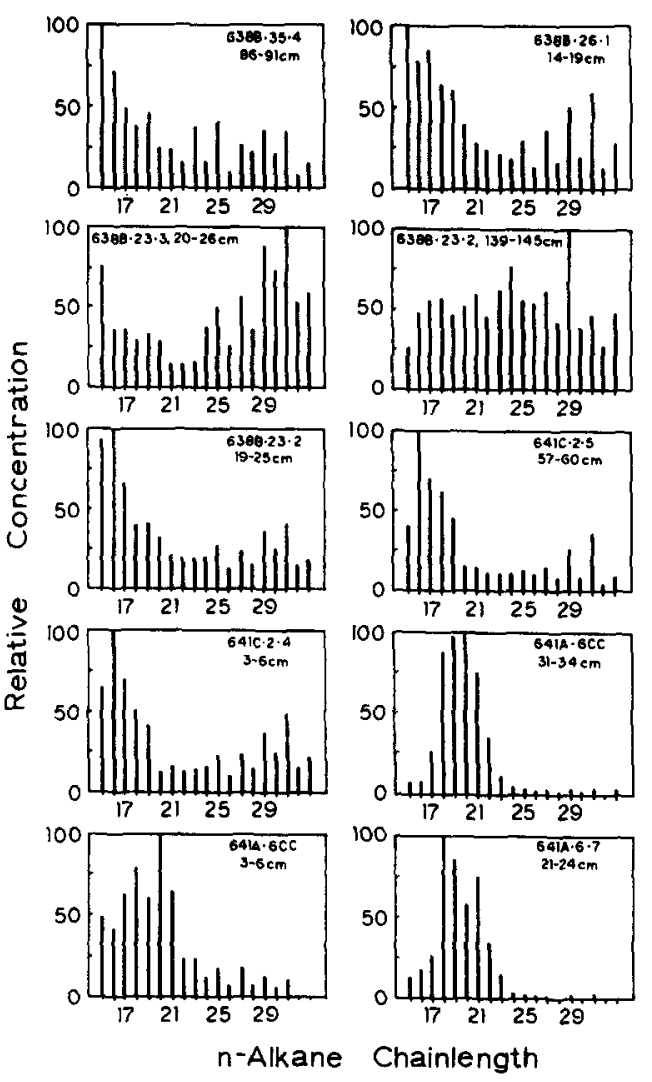

Fig. 3. Distributions of $n$-alkanes extracted from selected Leg 103 rocks. See Table 1 for descriptions of these samples.

higher for these samples (Table 2), the diminished proportions probably result from dilution by large amounts of the shorter chain-length components.

Distributions of extractable $n$-alkanoic acids are consistently dominated by $n$-hexadecanoic acid (Fig. 4), which is a ubiquitous component of all biota. A strong biotic character to the alkanoic acid distributions of these samples is reinforced by strong even-over-odd chain-length predominances. The well-preserved indication of the biological origin of these acids contrasts with the altered nature of the $n$-alkanes, a class of organic compounds which is considered significantly less susceptible to diagenetic alteration than are alkanoic acids. Long-chain acids indicative of land plant waxes $\left(C_{24}, C_{26}, C_{28}, C_{30}\right)$ are present in all the distributions, but at lower proportions than found in black shales from the BlakeBahama and Hatteras Formations at sites in the western Atlantic (Cardoso et al., 1978; Dunham et al., 1987). The difference in degree of preserved biological character between the $n$-alkanoic acid fractions and the less degradable $n$-alkane fractions suggests that the bulk of the fatty acid contents of these rocks is secondary, being derived from microbial populations that participated in the degradation of organic substances which were photosynthetically produced by aquatic and continental flora. This degradation most likely took place during and early after sediment deposition, and it appears to break 


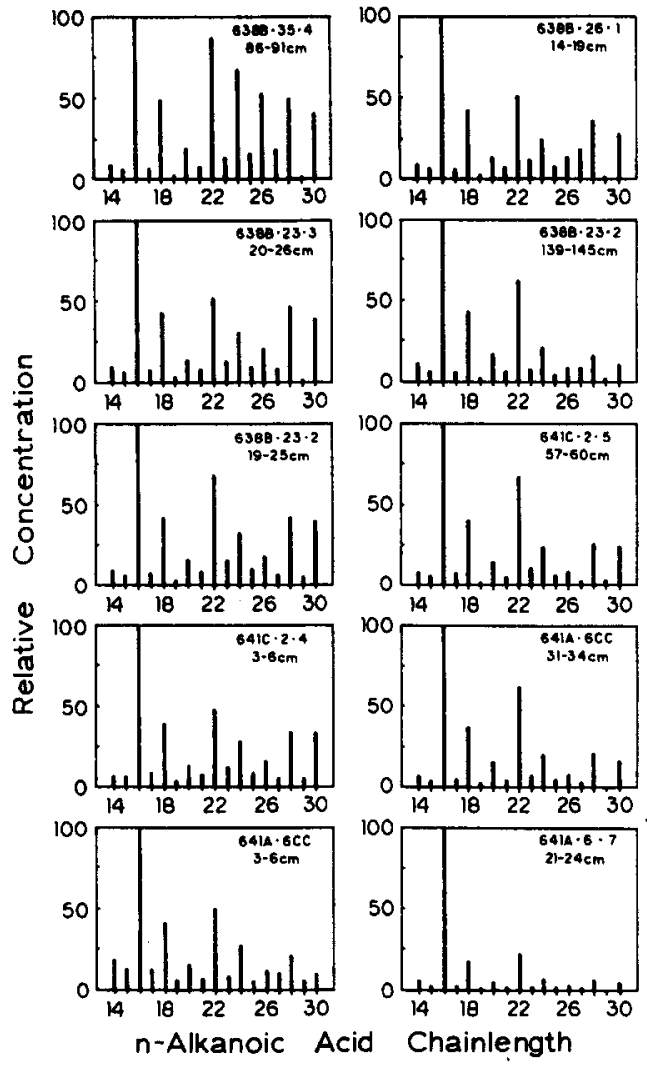

Fig. 4. Distributions of $n$-alkanoic acids extracted from selected Leg 103 rocks. See Table 1 for descriptions of these samples.

down shorter-chain-length geolipid components preferentially over the longer molecules (Matsuda and Koyama, 1977; Giger et al., 1980).

The $n$-alkanol distributions (Fig. 5) are dominated by three components. The $\mathrm{C}_{28}$ and $\mathrm{C}_{30} n$-alkanols, which have been interpreted to be indicators of terrigenous geolipids in marine sediments and rocks (Brassell et al., 1982), are especially dominant in the samples of black shale 638B-26-1, 14-19 cm (Hauterivian), 641C-2-4, 3-6 cm (Albian), and $641 \mathrm{~A}-6 \mathrm{CC}, 3-6 \mathrm{~cm}$ (Cenomanian). The most abundant $n$-alkanol in eight of the ten samples in Fig. 5 is $C_{22}$, which has been postulated to arise from microbial processing of sediment organic matter (Cranwell, 1981; Keswani et al., 1984), a possibility which is consistent with the $n$-alkanoic acid data. Like the $n$-acids, the even-over-odd carbon-chainlength predominance of these $n$-alkanols is high, indicating retention of the biological character of this geolipid fraction. These straight-chain alcohols are considered less likely to be preserved than are $n$ alkanes (e.g. Cranwell, 1981). Because the $n$-alkane fractions of these Leg 103 samples display evidence for their microbial alteration, it is likely the $n$-alkanol distributions reflect a combination of degradation (loss of shorter components, production of $\mathrm{C}_{22}$ ) and retention of originally deposited components (enhanced importance of $\mathrm{C}_{28}$ and $\mathrm{C}_{30}$ ).
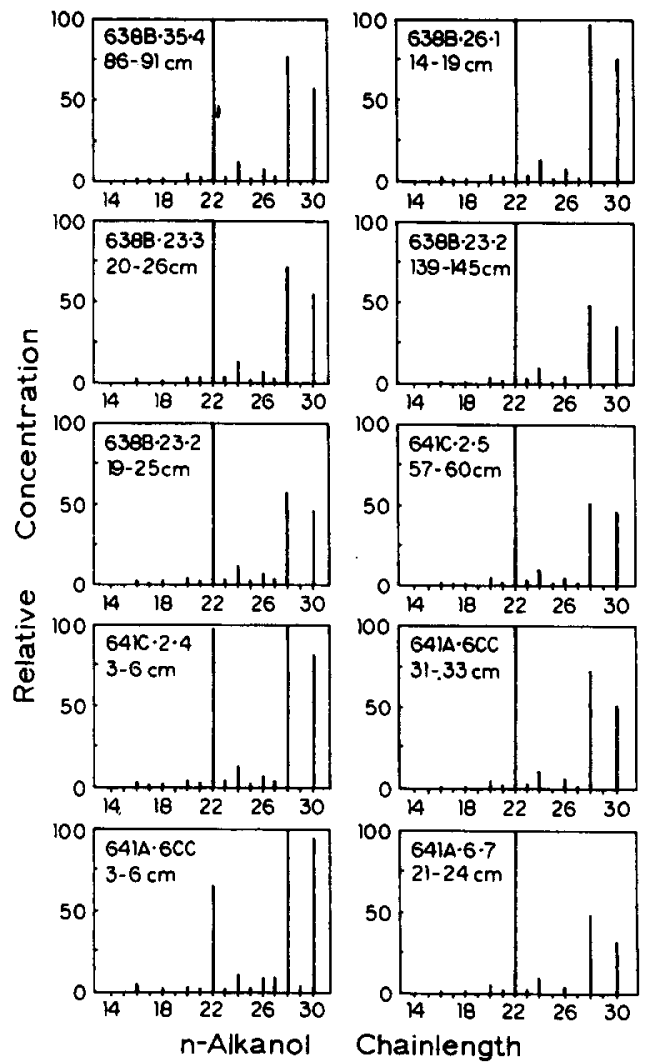

Fig. 5. Distributions of $n$-alkanols extracted from selected Leg 103 rocks. See Table 1 for descriptions of these samples.

\section{Paleoceanographic implications}

The amount and the geochemical character of organic matter contained within black shales and adjacent organic-carbon-poor rocks provide information about the paleoceanographic conditions leading to these contrasting types of deposits. Findings of black shales at a number of DSDP sites in the North Atlantic show that these atypical sediments accumulated in episodes generally restricted to Neocomian, Aptian-Albian, Cenomanian-Turonian and Coniacian ages (e.g. Arthur and Schlanger, 1979; Tucholke and Vogt, 1979; Thierstein, 1979; de Graciansky et al., 1981, 1982; Weissert, 1981; Waples, 1983; Stein et al., 1986). The black shales encountered by drilling on the Galicia Margin during ODP Leg 103 are less dramatically enriched in organic matter than those from many other parts of the Atlantic Ocean, yet they are important in providing the longest record of depositional history from a single area of the eastern part of the North Atlantic.

The organic matter present in the Neocomian black shales obtained from Hole 638B and from near-by Site 398 (Deroo et al., 1978) is a mixture of terrigenous material and of poorly-preserved marine material. These characteristics imply that during this syn-rift stage of development of the Galician margin land-derived organic matter abundantly accompanied the turbidities commonly found interspersed 
in the predominantly pelagic carbonate mode of sedimentation. Furthermore, the waters of this young basin were oxygenated, in agreement with bioturbation found commonly in the carbonates (de Graciansky and Chenet, 1979; Boillot et al., 1985) and resulting in poor preservation of the marine components of the organic matter. Marine productivity was probably not high.

Aptian-Albian black shales from the Galicia Margin are generally richer in their organic carbon content than their Neocomian counterparts, at least partly because they contain less carbonate material which can dilute the carbon concentrations. The type of organic matter present in these middle Cretaceous strata is similar to that in the Neocomian rocks, although slightly richer in its marine proportion. Conditions leading to accumulations of black shale were probably also similar-an oxygenated, turbiditic environment receiving land-derived materials from erosion of coastal areas.

The well-developed black shale occurrence in the abbreviated Cenomanian-Turonian section of Hole 64lA requires exceptional paleoceanographic conditions for its explanation. A period of high productivity, a greatly intensified and expanded oxygen minimum zone, or deepwater anoxia have been discussed as possibilities (e.g. de Graciansky et al., 1984; Arthur et al., 1986; Herbin et al., 1986; Stein, 1986). Enhanced proportions of marine organic matter and diminished sediment mass accumulation rates are two features common to Cenomanian-Turonian deposits in the Atlantic (Stein et al., 1986); both are consistent with the section from Hole 641A. The Leg 103 results appear to fit into the ocean-wide Cenomanian-Turonian puzzle. Micropaleontological data show that the oxygen minimum zone was well-developed at this time and reached higher onto the margin of the eastern North Atlantic Ocean (Hart and Ball, 1986), yet the Cenomanian-Turonian Boundary Event remains the best documented candidate for a basin-wide, bottom-water anoxic period in the geological record contained in the seafloor.

\section{SUMMARY}

(1) Three episodes of "black shale" deposition are represented in rocks obtained by drilling at Leg 103 holes on the Galicia Margin: Hauterivian-Barremian, Aptian-Albian, and Cenomanian-Turonian.

(2) The organic matter contained within the "black shales" and their adjacent organic-carbon-poor strata is a mixture of continental and marine material, displaying varying amounts of microbial reworking.

(3) Downslope transport and redeposition of sediments and entrained organic matter from shallower, nearshore or coastal sites was important to the accumulation of the Hauterivian-Barremian and Aptian-Albian episodes of black shales.
(4) Deepwater anoxia appears to have contributed to the deposition of organic-carbon-rich sediments in the short Cenomanian section in Hole 641A.

(5) The organic matter in these Galician Margin black shales is relatively lean in extractable geolipids and is geothermally immature, reflecting a history of low heat flow on this margin.

Acknowledgements - We thank the Ocean Drilling Program, funded by the National Science Foundation and IPOD countries, for providing the opportunity for K.W.D. to participate in Leg 103 and for making samples available to us. Carbon isotope analyses were performed under the direction of K. C. Lohman. Financial support was provided by a grant from JOI-USSAC.

\section{REFERENCES}

Arthur M. A. and Schlanger S. O. (1979) Cretaceous "oceanic anoxic events" as causal factors in development of reef-reservoired giant oil fields. Am. Assoc. Pet. Geol. Bull. 63, 870-885.

Arthur M. A., Schlanger S. O. and Jenkyns H. C. (1986) The Cenomanian-Turonian Oceanic Anoxic Event, II. Paleoceanographic controls on organic matter production and preservation. In Marine Petroleum Source Rocks (Edited by Brooks J. and Fleet A.). Blackwell, Oxford.

Boillot G., Winterer E. L. et al. (1985) Evolution of a passive margin. Nature 317, 115-116.

Boillot G., Winterer E. L., Meyer A. W. et al. (1987) Proc. Init. Rep. (Part A), ODP, 103. U.S. Govt Printing Office, Washington, D.C.

Brassell S. C., Eglinton G. and Maxwell J. R. (1982) Preliminary lipid analyses of two Quaternary sediments from the Middle America Trench, southern Mexico transect, Deep Sea Drilling Project Leg 66. In Init. Rep. $D S D P, 66$ (Edited by Watkins J. S., Moore J. C. et al.), pp. 557-580. U.S. Govt Printing Office, Washington, D.C.

Cardoso J. N., Wardroper A. M. K., Watts C. D., Barnes P. J., Maxwell J. R., Eglinton G., Mound D. G. and Speers G. C. (1978) Preliminary organic geochemistry analyses; Site 391, Leg 44 of the Deep Sea Drilling Project. In Init. Rep. DSDP, 44 (Edited by Benson E. W., Sheridan R. E. et al.), pp. 617-623. U.S. Govt Printing Office, Washington, D.C.

Craig H. (1953) The geochemistry of the stable carbon isotopes. Geochim. Cosmochim. Acta 3, 53-92.

Cranwell P. A. (1981) Diagenesis of free and bound lipids in terrestrial detritus deposited in a lacustrine sediment. Org. Geochem. 3, 79-89.

Dean W. E., Arthur M. A. and Claypool G. E. (1986) Depletion of ${ }^{13} \mathrm{C}$ in Cretaceous marine organic matter: Source, diagenetic, or environmental signal? Mar. Geol. $70,119-157$

Deroo G., Graciansky P. C. de, Habib D. and Herbin J.-P. (1978) L'origine de la matiere organique dans les sediments cretaces du site I.P.O.D. 398 (haut fond de Vigo): correlations entre les donnees de la sedimentologie, de la geochimie organique et de la palynologie. Bull. Soc. Geol. Fr. 7, 465-469.

Dunham K. W., Meyers P. A. and Dunham P. L. (1987) Organic geochemical comparison of Cretaceous black shales and adjacent strata from Deep Sea Drilling Project Site 603, outer Hatteras Rise. In Init. Rep. DSDP, 93 (Edited by Hinte J. E. van, Wise S. W. et al.), pp. 1195-1210. U.S. Govt Printing Office, Washington, D.C. Dunham K. W., Meyers P. A. and Ho E. S. (1988) Organic geochemistry of black shales and adjacent strata from the Galicia Margin, North Atlantic Ocean. In Proc. Init. Rep. $(P t B)$ ODP, 103 (Edited by Boillot G., Winterer E. L. 
et al.). U.S. Govt Printing Office, Washington, D.C. In press.

Eglinton G. and Hamilton R. J. (1963) The distribution of $n$-alkanes. In Chemical Plant Taxonomy (Edited by Swain T.), pp. 187-217. Academic Press, New York.

Erdman J. G. and Schorno K. S. (1979a) Geochemistry of carbon: Deep Sea Drilling Project, Legs 47A and 47B. In Init. Rep. DSDP, 47 (Pt 2) (Edited by Sibuet J. C., Ryan W. B. F. et al.), pp. 553-560. U.S. Govt Printing Office, Washington, D.C.

Erdman J. G. and Schorno K. S. (1979b) Geochemistry of carbon: Deep Sea Drilling Project Leg 48. In Init. Rep. DSDP., 48 (Edited by Montadert L., Roberts D. G. et al.), pp. 947-950. U.S. Govt Printing Office, Washington, D.C.

Giger W., Schaffiner C. and Wakeham S. G. (1980) Aliphatic and olefinic hydrocarbons in recent sediments of Greifensee, Switzerland. Geochim. Cosmochim. Acta 44, 119-129.

Graciansky P. C. de and Chenet P. Y. (1979) Sedimentological study of Cores 138 to 56 (upper Hauterivian to middle Cenomanian): An attempt at reconstruction of paleoenvironments. In Init. Rep. DSDP, 47 (Edited by Sibuet J.-C., Ryan W. B. F. et al.), pp. 403-418. U.S. Govt Printing Office, Washington, D.C.

Graciansky P. C. de, Bourbon M., Lemoine $M$. and Sigal L. (1981) The sedimentary record of mid-Cretaceous events in the western Tethys and central Atlantic Oceans and their continental margins. Eclogae Geol. Helv. 47, 353-367.

Graciansky P. C. de, Brosse E., Deroo G., Herbin J.-P., Montadert L., Muller C., Sigal J. and Schaff A. (1982) Les formations d'age Cretace de l'Atlantique Nord et Leur Matiere organique: paleogeographie et milieux de depot. Rev. Inst. Fr. Pet. 37, 275-337.

Graciansky P. C. de, Deroo G., Hervin J. P., Montadert L., Muller C., Schaff A. and Sigal J. (1984) Ocean-wide stagnation episode in the Late Cretaceous. Nature 308, 346-349.

Hart M. B. and Ball K. C. (1986) Late Cretaceous anoxic events, sea-level changes and the evolution of the planktonic foraminifera. In North Atlantic Paleoceanography (Edited by Summerhayes C. P. and Shackleton N. J.). Geol. Soc. Spec. Pub. 21, pp. 67-78.

Herbin J. P., Mondadert L., Muller C., Gomez R., Thurow J. and Weidmann J. (1986) Organic-rich sedimentation at the Cenomanian-Turonian boundary in oceanic and coastal basins in the North Atlantic and Tethys. In North Atlantic Paleoceanography (Edited by Summerhayes C. P. and Shackleton N. J.) Geol. Soc. Spec. Pub. 21, pp. $389-442$.

Jansa L., Gardner J. V. and Dean W. E. (1978) Mesozoic sequences of the central North Atlantic. In Init. Rep. DSDP, 41 (Edited by Lancelot Y., Seibold E. et al.), pp. 991-1031. U.S. Govt Printing Office, Washington, D.C.

Keswani S. R., Dunham K. W. and Meyers P. A. (1984) Organic geochemistry of late Cenozoic sediments from the subtropical South Atlantic. Mar. Geol. 61, 25-42.

Leenheer M. J., Flessland K. D. and Meyers P. A. (1984) Comparison of lipid character of sediments from the Great Lakes and the northwestern Atlantic. Org. Geochem. 7, 141-150.

Matsuda H. and Koyama T. (1977) Early diagenesis of fatty acids in lacustrine sediments-I. Identification and distribution of fatty acids in recent sediment from a freshwater lake. Geochim. Cosmochim Acta 41, 777-783.

Müller G, and Gastner M. (1971) The "KarbonateBombe," a simple device for determination of the carbonate content in sediments, soils and other materials. Neues Jahrb. Mineral. Monatsh. 10, 466-469.

Peterson B. J., Howarth R. W. and Garritt R. H. (1985) Multiple stable isotopes used to trace the flow of organic matter in estuarine food webs. Science 227, 1361-1363.

Risatti J. B., Rowland S. J., Yon D. and Maxwell J. R. (1984) Stereochemical studies of acyclic isoprenoidsXII. Lipids of methanogenic bacteria and possible contributions to sediments. In Aduances in Organic Geochemistry 1983 (Edited by Leythaeuser D. and Rullkötter J.). Org. Geochem. 6, 93-104. Pergamon Press, Oxford.

Sibuet J.-C., Mazé J.-P., Amortila P. and Le Pichon X. (1987) Physiography and structure of the western Iberian continental margin off Galicia, from Sea Beam and seismic data. In Proc., Init. Rep. (Pt A), ODP, 103 (Edited by Boillot G. and Winterer E. L.), pp. 77-97. U.S. Govt Printing Office, Washington, D. C.

Simoneit B. R. T. (1978) The organic chemistry of marine sediments. In Chemical Oceanography (Edited by Reily J. P. and Chester R.), Vol. 7, pp. 233-311. Academic Press, London.

Simoneit B. R. T. (1986) Biomarker geochemistry of Black Shales from Cretaceous oceans-An overview. Mar. Geol. 70, 9-41.

Stein R. (1986) Organic carbon and sedimentation ratefurther evidence for anoxic deep-water conditions in the Cenomanian/Turonian Atlantic Ocean. Mar. Geol. 71, 199-209.

Stein R., Rüllkotter J. and Welte D. H. (1986) Accumulation of organic-carbon-rich sediments in the Late Jurassic and Cretaceous Atlantic Ocean-A synthesis. Chem. Geol. 56, 1-32.

Thierstein H. R. (1979) Paleoceanographic implications of organic carbon and carbonate distribution in Mesozoic deep-sea sediments. In Deep Drilling Results in the Atlantic Ocean: Continental Margins and Paleoenvironment (Edited by Talwani M., Hay W. and Ryan W. B. F.), pp. 249-274. Am. Geophys. Union, Washington, D.C.

Tucholke B. E. and Vogt P. R. (1979) Western North Atlantic: Sedimentary evolution and aspects of tectonic history. In Init. Rep. DSDP, 43 (Edited by Tucholke B. E., Vogt P. R. et al.), pp. 791-825. U.S. Govt Printing Office, Washington, D.C

Waples D. W. (1983) Reappraisal of anoxia and organic richness, with emphasis on Cretaceous of North Atlantic. Am. Assoc. Pet. Geol. Bull. 67, 963-978.

Weissert H. (1981) The environment of deposition of black shales in the Early Cretaceous: An ongoing controversy. In The Deep Sea Drilling Project: A Decade of Progress (Edited by Warme J. E., Douglas R. G. and Winterer E. L.) Soc. Econ. Paleontol. Mineral. Spec. Publ. 32, pp. $547-560$. 